\title{
On the Legacy of Translation Theories from the 1950s and 1960s: A Critical Review
}

\author{
${ }^{*}{ }^{1}$ Lindsay Chaves-Fernández \\ lindsay.chaves.fernandez@una.ac.cr \\ ${ }^{2}$ Henry Sevilla-Morales \\ henry.sevilla.morales@una.ac.cr \\ ${ }^{1 \& 2}$ Universidad Nacional, Costa Rica
}

Received: 25.01.2020 • Accepted: 01.03.2021 • Published: 31.03.2021 • Final Version: 031.03.2021

Abstract: Translation theories which bloomed in the 1950s and the 1960s have inspired numerous debates on multiple contexts of theory and praxis. With the increase of specialized journals and publishing houses of the past few decades, the professional literature has gone in so many directions -with supporters and opponents alike - that it is often hard to strike a balanced view of the contributions of these theories to current translation studies. In an attempt to fill this gap, this theoretical review article examines a corpus of scholarly publications which have taken place mainly between 2002 and 2018 about the translation theories proposed in the 1950s and 1960s. To such end, a body of works focusing on the seminal works of Vinay and Darbelnet (1958), Jakobson (1959), Nida (1964a), Catford (1965), and Nida and Taber (1969) are reviewed to infer their degree of applicability to current translation-based discussions and praxis. Findings suggest that the authors exerting the greatest influence on contemporary discussions of translation studies seem to be Vinay and Darbelnet, followed by Nida and Taber, and then by Jakobson and Catford. They also indicate that the degree to which the translation theories under question are obsolete (or not) is hard to determine with accuracy. It remains unclear whether the bulk of publications which these theoreticians inspire is the product of acceptance or rejection of the assumptions contained in their postulates.

Keywords: Vinay; Darbelnet; Nida; Taber; Jakobson; Catford.

Resumen: Las teorías de la traducción que surgieron en los años 50 y 60 han generado grandes debates en múltiples niveles tanto en la teoría como en la praxis. Con el aumento de las revistas especializadas y casas editoriales de las últimas décadas, la literatura profesional ha tomado tantos caminos (con adherentes y detractores por igual) que a menudo resulta difícil lograr una visión equilibrada de los aportes de dichas teorías a los estudios de traducción actuales. Con el fin de acortar esta brecha, el presente artículo de revisión se plantea examinar un corpus de publicaciones académicas llevadas a cabo entre el 2002 y el 2018 sobre las teorías de traducción propuestas en los años 50 y 60. Para ello, se escudriñaron una serie de trabajos que versaban sobre el trabajo pionero de Vinay y Darbelnet (1958), Jakobson (1959), Nida (1964a), Catford (1965) y Nida y Taber (1969) con el propósito de deducir su grado de aplicación en la teoría y la práctica actual sobre traducción. Los hallazgos sugieren que los autores que ejercen una influencia más decisiva en las discusiones contemporáneas sobre estudios de traducción son Vinay y Darbelnet, seguidos por Nida y Taber; a estos les suceden Jakobson y Catford. Asimismo, se subraya se determinar el grado de obsolescencia (o ausencia de ella) no se puede determinar de manera fehaciente. Por último, queda por averiguar si el volumen de

\footnotetext{
* Corresponding Author: Lindsay Chaves-Fernández
} 
publicaciones que estos autores han inspirado es el resultado de la aceptación o más bien del rechazo de los supuestos en los cuales se basaron sus postulados.

Palabras clave: Vinay, Darbelnet, Nida, Taber, Jakobson, Catford

\section{Introduction}

Although the field of translation studies is vindicated an academic discipline in its own right today (Munday, 2016), its formal inception dates back to at least the first century A.D., with the philosopher Cicero and the later advancements of the priest Saint Jerome of Stridon (4th and 5th A.D.), whose seminal works set the grounds for the major theories which would bloom in the many years to come (Cagnolati, 2012). In the more contemporary era of translation studies, the 20th century would see the rise of translation as an even more pervasive field (Cagnolati, 2012), characterized by an explosion of scholarly publications seeking to problematize the ways in which translation is understood and brought to practice, and marked by a steady move towards defining translation on the part of scholars such as Vinay and Darbelnet (1958) and Catford (1965) (Cagnolati, 2012).

Today, a number of studies acknowledge the importance of theories which came into light during the 1950s and 1960s (Absalan \& Falahati, 2016; Baker, 2005, in Kittel et al., 2005; Delisle, 2006; Jixing, 2013; Kalantari \& Karimnia, 2011; Molina \& Hurtado, 2002; Olfi \& Sunardi, 2017; Pym, 2014; Pym \& Ayvazyan, 2015; Waliński, 2015). While in the eyes of some critics these contributions are rather obsolete, our critical review shows that, in varying degrees, their discussions appear more relevant than ever in a host of current studies. In fact, some recent publications have undertaken sharp discussions on the issue (e.g., Bassnett, 2014; Chesterman, 2017; Cheung, 2009; Ray, 2008), and they seem to suggest that, although their views are not necessarily in line with the ones proposed in the 1950s and 1960s, the works from these two decades continue to inspire considerable professional debate and controversy today.

From our initial review of these articles, we hypothesized that much of the criticism geared against these theories in current academia is largely misinformed and, perhaps unknowingly, the result of facile generalizations that tend to equate old to obsolete, which in turn portrays a distorted view of the actual value of these theories and the debates they are likely to inspire in the years to come. To test the above hypothesis empirically, this paper surveys the theoretical discussions which have taken place mainly between 2002 and 2018 about the theories proposed in the 1950s and 1960s in order to strike a balanced perspective on the subject. In doing so, a corpus of articles addressing the seminal works of Vinay and Darbelnet (1958), Jakobson (1959), Nida (1964), Catford (1965), and Nida and Taber (1969) are reviewed to infer their degree of applicability in current translation-based discussions and praxis. At the core of this work are the following guiding questions:

1. Which authors from the 1950s and 1960s hold a stronger theoretical presence in contemporary discussions of translation studies?

2. To what degree are the translation theories proposed by the authors from the 1950s and 1960s truly obsolete in theoretical debate and in professional praxis? 
3. What is the overall relevance of the translation theories proposed in the $1950 \mathrm{~s}$ and 1960s in the first two decades of 21st century translation studies?

Taken together, findings suggest that claims on the obsolescence of the translation theories studied are sterile and should therefore be abandoned to refocus attention on the theoretical and practical debates that they inspire today. The study is significant as it sheds light on two major aspects: (1) it assists our understanding of the relevance of the translation theories proposed in the 1950s and 1960s in the field of translation and (2) albeit moderately, it provides insights into the curricular decision-making process in translationbased study programs.

For purposes of organization, this theoretical review comprises studies from different geographical areas organized thematically and chronologically; that is, the studies are grouped according to the theoreticians they touch upon, but also by year of publication to assess the evolution of the discussions through time. The lines ahead, hence, cover four subsections: (1) On Jean Paul Vinay and Jean Darbelnet, (2) On Roman Jakobson, (3) On J. C. Catford, and (4) On Eugene Nida and Charles Taber.

\section{Literature Review}

\subsection{On Jean Paul Vinay and Jean Darbelnet}

French-Canadian Jean Paul Vinay and French Jean Darbelnet are considered the pioneers of seven translation techniques that have inspired a plethora of theoretical and practical discussions within the realm of translation studies. In their seminal work, Stylistique comparée du français et de l'anglais (1958), they presented "the first classification of translation techniques that had a clear methodological purpose" (Molina \& Hurtado, 2002, p. 499). These scholars are probably best remembered for their categorization of seven translation procedures into two main groups: (1) direct or literal translation, consisting of borrowing, calque, and literal translation; and (2) oblique translation, comprising transposition, modulation, equivalence and adaptation (Molina \& Hurtado, 2002).

Our critical review, thus, begins with Molina and Hurtado's Translation Techniques Revisited. A Dynamic and Functionalist Approach, a 2002 paper that sought to clarify the notion of translation technique, motivated by the fact that over the years the definition of this concept has remained ambiguous, even contradictory, within the professional field of the academy. In order to accomplish this, the authors present a critical review of previous definitions and classifications of the term; then, they redefine such concepts by drawing a sharp distinction between "translation method and translation strategies" (p. 498); and lastly, they propose their own categorization of translation techniques based on a study of the translation of cultural elements in the Arabic translation of the novel One Hundred Years of Solitude by Gabriel García Márquez.

In the review of different approaches to classifying translation techniques, Molina and Hurtado also survey theoreticians such as Nida (1964), Nida and Taber (1969), Margot (1969), Vásquez Ayora (1979), Newmark (1988), Delisle (1993), and many others which are for now outside the scope of our paper. A critical review of all these techniques is made 
and some definitions are proposed, differentiating between translation method, strategy, and technique.

Two years later, Pym would publish Vinay and Darbelnet and the Politics of Translation Solutions, a frontal critique of the applications of the translation solutions proposed by Vinay and Darbelnet in the 1950s and their connection with the political interests that underlie the seemingly only technical proposal of the authors. With magnificent irony, Pym criticizes the naive notion that translators are only channels of transmission of linguistic symbols between languages. On the contrary, he explains that translators are the channel through which powerful groups disseminate their messages, making the former the intermediaries of power relations that often go unnoticed in the eyes of the average citizen. Among many other criticisms to the contributions of Vinay and Darbelnet, Pym (2014) argues against the monolingual perspective from which the arguments of these translation solutions were forged, "Vinay and Darbelnet's stylistics thereby stays clear of translations; it does not trust them: translations always risk contamination. Authority and purity are magically located in "a monolingual brain," which is somewhere else, back in Paris" (Pym, 2014, p. 4).

The author goes on to add that

this translation method is glossed as "a set of rules that govern the miracle of a perfect translation," which is indeed miraculous. Given the multiplicity of voices hanging around, who or what could ever pretend to recognize the perfect translation? Perhaps only the French forefathers, who speak through the travelling French linguists, protected from contamination by methodless linguistics. (p. 6)

Pym concludes by criticizing the wave of scholars who have cited, recited, and recycled Vinay and Darbelnet's translation solutions for approximately 50 years. He stresses that despite the value that they may have held (and that seem to continue to hold, to some extent), these postulates were raised taking two colonial languages (English and French) as models, so their validity should be reviewed with a very critical eye. Added to this is the fact that the notion of equivalence was never operationalized by these authors. Put simply, the implied argument is that in the analysis of what is proposed by Vinay and Darbelnet, one must always keep in mind the new contexts in which one tries to apply old solutions.

Along the same lines, in 2015 Waliński published Translation procedures. Ways to Translation, a book chapter where the taxonomy of the translation procedures of Vinay and Darbelnet (1958) is reviewed and became seminal work for the creation of later taxonomies on translation techniques. The direct translation procedures (borrowing, calque, and literal translation) and oblique procedures (transposition, modulation, equivalence, and adaptation) proposed by these authors are outlined, and several examples are displayed to facilitate the understanding of each of these techniques. Waliński (2015) concludes that although the contributions of Vinay and Darbelnet have been the subject of criticism, especially since they are a comparison of two language systems (French and English) at the level of words, phrases, and sentences out of context, it became a pioneering work for future taxonomies. For Waliński, the contributions of these two authors are a vital starting point for the work that would come along in this theoretical line of translation. Furthermore, he proposes that Vinay and Darbelnet's theories must be carefully studied so that we can look beyond the simple structural alterations between two languages and give 
way to a creative translator, capable of mediating between the author's message and the target audience in a process of translation-mediated communication.

In the same year, Pym and Torres-Simón showcased the results of using two closely aligned translation typologies which were popular in the 1950s: the one by Vinay and Darbelnet (1958) and the one proposed by the Chinese author Loh Dian-yang (1958). Data were collected from four translator-training classes at a master's program where students had to translate into European and Asian languages. Findings are that students working with Chinese felt more comfortable using Loh's model, while those working with European languages found it easier to use the one proposed by Vinay and Darbelnet. While these findings are far from controversial in themselves, what is more revealing is that: (1) students from both sides were able to describe and criticize both models regardless of their cultural backgrounds, and (2) the solution types allowed for reflection on theory and practice, for "when they $\operatorname{tr}[i e d]$ to categorize their translation solutions, students reflect[ed] both on their work and on the difficulties of theorization" (Pym \& Torres-Simón, 2015, p. 101). "If there is pedagogical value in these activities," the authors argue, "it lies in that double process, rather than in the lists of solution types themselves" (Pym \& Torres-Simón, 2015, p. 101). These authors also conclude that implementing these translation solution types continues to be a successful practice nowadays, but students claim it is necessary to revisit some of the categories to have a more complete and thorough technique package.

Along the same thematic lines, Absalan and Falahati recently published a paper titled Study of Translation Strategy Applications in Clothing Brand Advertising Slogans in Iran. The authors deal with the English-to-Persian application of translation studies in the translation of clothing brand advertising slogans in Iran. Three groups of translators sampled through availability sampling participated in the study: B.A. translation students, M.A. translation students, and M.A. English translation instructors. Using Vinay and Darbelnet's (1995) model, Absalan and Falahati note that the three groups "used the seven strategies [of Vinay and Darbelnet] differently" (2015, p. 174), and that the most used technique by the three groups of informants was literal translation. The authors indicate that the least frequently used technique by students and M.A. instructors was borrowing, while for B.A. students it was adaptation (2015, pp. 174-175). Absalan and Falahati discuss limitations of the study such as sample size, the use of a single model of analysis, among others which, as they acknowledge, restrain generalizability of results to larger populations.

In the same year, Rull, Ismail, and Keong (2016) published an article on the use of Vinay and Darbelnet's (1995) and Koponen's (2010) model to assess the accuracy of Malay translations of subtitles for 18 English films which involved sexual references and profane language. According to the authors, the issue merited attention because subtitling English films containing these characteristics has always represented a challenge for Malay translators since, for the most part, sexual references and foul language are usually "toned down or disregarded in the target language subtitles due to their taboo nature" (Rull et al., 2016, p. 371). Guided by the questions: (1) "What are the translation procedures used in English-Malay subtitling in relation to sexual references and profane language?" and (2) "What are the types of errors made in the translation of sexual references and profane language from English into Malay?", the authors concluded the following: (a) the most prevalent translation procedures were "equivalence" and "literal translation". In the cases where equivalence was used, the causes could be linked to the need to bridge semantic gaps left by the use of obscene English language which does not exist "in the culture of Malay 
language society" (Rull et al., 2016, pp. 378-379); and (b) the most common error made by the Malay translators was omission because, again, obscenities of this sort are "deemed inappropriate in Malay society" (Rull et al., 2016, p. 379). The authors claim that the study of this research problem yields insights on the attitudes and social (un)acceptability of profane language in rated films in the Malay culture.

One year later, Behtash and Moghadam (2017) would publish Translation Evaluation: A Comparative Study of an Oblique Translation, an empirical study examining the use of an oblique translation of a text from English into Persian. To such end, 110 randomly selected sentences from the Saleh Hosseini and Massumeh Nabizadeh's Persian translation of Orwell's Animal Farm were chosen "and compared [...] with their Persian counterparts" (Behtash and Moghadam, 2017, p. 108). The authors surveyed the most common translation procedures proposed by Vinay and Darbelnet in their mother categories of direct and oblique translation: borrowing, calque, literal translation, transposition, modulation, equivalence, and adaptation. Then, they review other common approaches to text translation, such as the ones proposed by House (2015) and Jakobson (1959). By conducting a chapter-by-chapter analysis of the Persian translation of the source text, the researchers found out that equivalence accounted for the most frequently used translation procedures $(45 \%)$, followed by modulation (32\%) and transposition (24\%), with adaptation at the end of the frequency continuum $(2 \%)$.

Similar to Behtash and Moghadam, in 2017 Sharei published A Comparative Study of the Strategies Employed in "The Old Man and the Sea" Translated from English into Persian on the Basis of Vinay and Darbelnet's Model, an inquiry focusing on the ways in which Vinay and Darbelnet's translation procedures were employed in the Persian translation of the referred Hemingway's novel by two different translators: Najaf Daryabandari and Mohammad Taghi Faramarzi. The study also investigated which of the two categories (direct or oblique translation) prevailed in the Persian version of these translators. After outlining general principles of translation, the connection between translation and culture, some broad considerations on literary translation, the specificities of the translation of novel, and Vinay and Darbelnet's translation procedures, the researcher described their methodology as follows: The novel was first carefully read in order to identify instances of direct and oblique translation. Then, samples reflecting these techniques were identified and put into comparative tables. These were in turn analyzed in the light of the seven translation procedures by Vinay and Darbelnet and then categorized as direct or oblique translation. Findings are that: (1) Modulation strategy has the highest frequency in Najaf Daryabandari's translation; (2) literal translation had the highest frequency in Faramarzi's translation; (3) adaptation occurred just in Faramarzi's translation and there is no adaptation in Daryabandari's version; and (4) indirect translation had the highest frequency in Daryabandari's translation while direct translation strategy has the highest frequency in Faramarzi's translation (Sharei, 2017).

In different ways and from varying theoretical lenses, the articles reviewed above add up to the bulk of literature evidencing the legacy of Vinay and Darbelnet in today's discussions of translation techniques. While our corpus is by no means extensive, it allows to conclude that these two theoreticians continue to influence translation studies across multiple academic settings from around the world. The lines ahead offer an account of the discussions around another popular theoretician from the late 1950s. 


\subsection{On Roman Jakobson}

Roman Jakobson was a Russian-American linguist and literary theorist, who back in 1959, in his essay On Linguistic Aspects of Translation, proposed a tripartite division of translation (Jia, 2017). For Jakobson, understanding a word is a linguistic phenomenon and when trying to understand and translate a word, three kinds of translation might take place, namely intralingual translation or rewording, interlingual translation or translation proper, and intersemiotic translation or transmutation (Jakobson, 1959).

After a careful examination of Jakobson's claims, it is safe to conclude that they have been abused and misused by some scholars succeeding him. So, in order to better understand Jakobson in the translation studies field, in 2008, in her paper Roman Jakobson and the Topic of Translation: Reception in Academic Reference Works, Sütiste claims that while Jakobson's contributions to several disciplines (e.g., translation studies, linguistics, and semiotics) have been studied and published, there seems not to be a clear link between his ideas of language and communication and translation. The aim of this article, thus, was to assess the above assertion and to study the connections between Jakobson and translation studies "focusing on a selection of works that by their definition strive for a balanced, wide and full coverage of a subject" (Sütiste, 2008, p. 272). To do so, the author conducted bibliographical research in nine encyclopedias covering three fields of study: linguistics, semiotics, and translation studies (three encyclopedias per field). Findings are that, in the three disciplines, connections were clearly established between Jakobson and translation studies; surprisingly, the general perception of Jakobson's legacy is mainly based on two of his articles (out of the several hundred works he published) and to a large degree "ignores the logic of Jakobson's thought as it manifests in his different works (i.e., there are few connections made between his ideas expressed in his different works)" (Sütiste, 2008, p. 271).

Along the same lines, in Jakobson and the Mental Phases of Translation Osimo (2009) discusses the relevance of Roman Jakobson in elucidating the mental process of translation. The author begins by reviewing Charles Peirce's notion of "interpretant" (the effect of a sign on someone who reads or hears it from verbal speech) and Vygotsky's "inner speech" (a form of internalized dialogue with oneself). Osimo proposes that when Jakobson spoke about interlingual, intralingual, and intersemiotic translation, he was not speaking about three differing types of translation, but about a conjunction of processes which make up a whole. In the first case, words from other languages are used; in the second, paraphrases in the same language are employed; and in the third one, an object is named in another sign system. In other words, Jakobson advocated for the "mixed nature of every translation process" (Osimo, 2009, p. 73). After an exhaustive review of theoretical principles underlying Jakobson's "revolutionary thought" (Osimo, 2009, p. 74), the author concludes that Jakobson has been misunderstood by scholars throughout the years in an essential aspect: The so-called tripartition of the translation process is not really a tripartition, but a complex activity which encompasses several complementary processes. Therefore, Osimo claims, the need for cooperative, interdisciplinary efforts with psychology and neuroscience experts becomes an even more necessary step for translation practice.

Leaving aside criticism of Jakobson's theories, in Compulsive Translators: Are Narrators in Javier Marías's Novels Beguiled by Language? Pérez-Carbonell (2017) analyzes the ways in which the narrators in four of Javier María's novels digress and 
constantly engage in discussions on language and translation, and then "discusses the effects of [Jakobson's] intralingual and intersemiotic translation on the narrators of Javier María's novels" (p. 338). As the observant characters in Marías's novels engage in compulsive (and often erratic) analyses of other characters' speeches and non-verbal communication, the use of intersemiotic translation becomes central in their interpretation of elements such as body language and intonation, while intralinguistic serves as a mechanism for them to infer meanings and language subtleties in various communicative events and settings in throughout the plot. The author concludes that, in the four novels examined, "reflections on language choice and the ramifications of interlingual translation contribute towards the complex depiction of Marías's narrators" (Pérez-Carbonell, 2017, p. 349).

In the same year (2017), in Roman Jakobson's Triadic Division of Translation Revisited, Jia undergoes archival research to revisit the influence of Jakobson's triadic division of translation (intralingual, interlingual, and intersemiotic) and thus explain how Jacobson's main theoretical opponents (which, according to Jia (2017), include Gideon Toury, 1986; Umberto Eco, 2001; Peeter Torop, 2002; Dinda Gorlée, 2010; Zhonglian Huang, 2015; and Hongwei Jia, 2016b and 2016c) came up with their own models and how, in turn, such models were subject to their own drawbacks and limitations. In essence, the aim of Jia's (2017) paper is [to criticize] Jakobson's tripartite division of translation with reference to the broad sense of translation and sign as technical terms and reconstruct [...] them in light of Lotman's conceptions of semiosphere (1984) to construct a translation typology and to promote translation semiotics as an emerging discipline.” (p. 33)

Jia (2017) concludes that, "after the re-analysis in terms of translation semiotics," her study reveals that "the previous reviews are mostly confined to conventional translation, i.e., translation proper, without considering the definitions of sign in the broad and narrow senses, and meanwhile neglecting the differences between the signifieds and definitions of the term translation in the broad and narrow senses" (p. 43).

Jia (2017) also offers the following highlights: (1) Jakobson is still "anchored" to binary oppositions of structuralism and accepts the idea of equivalence as a linear phenomenon between source and target language; (2) "he revises but weakens the relevancy between object and interpretant in the triadic semiotic relations, and is still confined to the binary oppositions to drag the relations between object and interpretant into a dual context, forcing the significance of a sign (which is, in fact, the significance of interpretant) to be a function of the context, which is inconsistent with the semiotic notion of an interpretant transformable into a sign through endless interpretations;" (3) he ignores the role humans' intermediary language in the translation process; and (4) "His division is inadequate in that he does not take into account the transformation between tangible signs, for instance, inverse or reverse translation, cotranslation, retranslation, transedition, just to name a few, and the translation from intangible signs to tangible ones as well" (pp. 43-44).

Following Osimo's (2009) thematic footsteps, in 2017 Da Silva investigated Jakobson's notion of intersemiotic translation in Asterix (a French character) comics. The analysis consisted of a comparison of pairs of comic frames (drawings) translated from French to Brazilian Portuguese to determine how the translator handled the various communication modes involved, such as "words, typography, object images, human expressions and gestures, layouts", etc. (Da Silva, 2017, p. 73). Findings suggest that in 
terms of modes (or semiotic systems), the Brazilian Portuguese translations used more than a single mode to translate another, for instance, the translation of a gesture into a word, in order to bridge gaps between the cultural systems of the two languages. Just like Osimo (2009), Da Silva (2017) seeks to re-elaborate commonly held assumptions on Jakobson's notion of intersemiotic translation, stressing the fact that Jakobson himself never explained what he really meant by it. This has led to the widespread misunderstanding that transmutation is the simple passage of, say, a movie into a video game or vice-versa and has therefore neglected the study of how intersemiotic translation is intertwined with other modes of translation. According to the author, we could hypothesize that one of the reasons Jakobson did not draw his attention to some semiotic forms of communication like images and gestures is that much of his contributions came into fruition from 1920 to 1960, a time where the use of images in the way we conceive them today was still under development.

The above were some of the most relevant papers around Roman Jakobson's postulates which still trigger research about translation theories in current investigations. The following section deals with professional literature on another prominent scholar within the realm of translation studies: J. C. Catford.

\subsection{On J. C. Catford}

Three years into the 21st century, Walters (2002) published From Linguistic Monument to Social Memory: Translation Strategies in Philip Polack's Version of Espriu's Primera historia D'Esther, an article presenting two translation categories by J. C. Catford: (1) linguistic and (2) cultural translation, and how they can be applied to Philip Polack's version of "Primera història d'Esther." In the first category (linguistic translation), the author includes techniques such as transliteration and paraphrase; however, when it comes to the second one (cultural translation), Polack keeps the genre and the play, but changes the main setting. Thus, in the original text the play takes place in the legendary Catalan community of Sinera, whereas in the translation, Polack moves it to South Wales.

In addition to the above, Walters (2002) highlights the inadequacy of using terms such as accuracy, closeness, and fidelity to describe a translation since these concepts are imprecise and subjective. He further elaborates on how transplanting and transposing (cultural translation strategies) and transliteration and paraphrase (linguistic translation strategies) are not only permissible but complementary. The author also exhorts translators to add some sophistication and adaptability to their translations "to be true to their readers" (2002, p. 876). Walters concludes that with Polack's translations (as well as with all translators which we could deem of high value), there is no such thing as a finished product. "Instead," he contends,

we are given a continuation of the source that is provisional rather than definitive. This affords not only the illumination of the original text and its accommodation through translation in the target literature but also, more radically, the making of another text." (Walters, 2002, p. 876)

About years later, in 2005 Baker authored Linguistic Models and Methods in the Study of Translation, a publication addressing the close relation between linguistics and translation studies as proposed by J. C. Catford. Based on the premise that a lot of the criticism against linguistic approaches to translation today is generally misinformed, the author critiques an outdated view of linguistic theory which is no longer representative of current approaches to linguistic translation. Thus, Baker surveys the main developments of 
such theory in translation theory to balance their achievements against their drawbacks from the early 1950s to the late 1990s. According to the author, generative linguists such as Noam Chomsky never showed much of an interest in translation studies; Catford, for his part, devoted articles and even an entire book to the subject, but he saw translation as an essentially mechanical transference of "the replacement of textual material in one language with textual material in another language" (Baker, 2005, p. 3). On reviewing the contributions of several scholars to translation studies, Baker concludes that the field as we know it today is much more diverse than it once was, which prompts scholars to profit from a variety of tools and perspectives, which, collaterally, makes it hard to categorize their contributions as "“linguistically-" or "non-linguistically-oriented"” (Baker, 2005, p. 8).

Along similar lines, in 2011 Kalantari and Karimnia published Catford's Shift Model of Translation: A Drama-Based Critical Inquiry, where, as the paper name suggests, they revisit Catford's shift model of translation in the context of drama translation. The authors are critical of current applications of this model to the translation of drama since, in their own words, "dramas differ from other types of scripts in that they are written to be played and the translation should evoke the same response to what has already been evoked by the original" (Kalantari \& Karimnia, 2011, p. 5012). Placing 20 randomly selected sentences from Woody Allen's 1975 play Death Knocks and its translation by Hooshang Hessami under question, the authors propose that more critical research on the applicability of Catford's model should be conducted to identify its limitations in the translation of dramas. Kalantari and Karimnia further conclude that some kinds of shifts have not been theorized yet, which may have profound implications for playwrights and dramatists alike, and that this should be considered more explicitly in translation training courses.

Winding up the corpus of studies around Catford, in 2018 Mirza Suzani published Applying Catford's Category Shifts to the Persian Translations of Three English Romantic Poems, a research article seeking to assess the degree to which Catford's category shifts had been applied in the Persian translations of three English poems by Abjadian. The poems were William Blake's “The Chimney Sweeper," Samuel Taylor Coleridge's Kubla Khan, and John Keats' "To Autum" (Mirza Suzani, 2018, p. 25). The author found that a total of 97 instances of shifts in the three poems, with types, number and percentage of shifts per poem distributed as follows:

\begin{tabular}{|l|c|c|c|c|}
\hline & Structural & Class & Unit & $\begin{array}{c}\text { Intra- } \\
\text { system }\end{array}$ \\
\hline $\begin{array}{l}\text { "The Chimney } \\
\text { Sweeper" }\end{array}$ & 14 & 0 & 3 & 4 \\
\hline "Kubla Khan" & 28 & 3 & 6 & 7 \\
\hline "To Autum" & 22 & 3 & 3 & 4 \\
\hline Total Number of Shifts & 64 & 6 & 12 & 15 \\
\hline Percentage & 65.97 & 6.18 & 12.36 & 15.45 \\
\hline
\end{tabular}

Table 1. Source: Table 4. The Number and Percentage of the Shifts in the Translation of All Three Poems, by Mirza Suzani, 2018, p. 34.

In the view of the author, the study suggests that "shifts are inevitable because of the different nature of languages and variations that exist among them" (Mirza Suzani, 2018, p. 35 ); therefore, the translator must necessarily "deviate" from the structures of the source 
text and adjust his translation to comply with that of the translated text (Mirza Suzani, 2018, p. 35).

\subsection{On Eugene Nida and Charles Taber}

To start this section, we will first take a glance at the contributions by Eugene Nida in the early 60s and some of the papers that have been published in recent years revolving around Nida's postulates. From then on, will move onto the articles discussing the legacy of Eugene Nida and Charles Taber as a team.

In 1964, US linguist Eugene Nida published Toward a Science of Translating with Special Reference to Principles and Procedures Involved in Bible Translating, a pioneering work that comprised the essence of the now well-known theory of dynamic equivalence for bible translation. According to Molina and Hurtado (2002), this author -with the later contributions of Taber (1969) and Margot (1969)- focused on solving issues of cultural transfer when no equivalent was available in the target language. Thus, he proposed three categories of techniques: "additions, subtractions and alterations," which are employed to: "(1) to adjust the form of the message to the characteristics of the structure of the target language; (2) to produce semantically equivalent structures; (3) to generate appropriate stylistic equivalences; (4) to produce an equivalent communicative effect" (Molina \& Hurtado, 2002, p. 502). In an attempt to outline the state of affairs around the work of Nida, we offer a review of the main publications discussing his legacy in the lines that follow.

In Truth and Fullness of Meaning. Fullness versus Reductionist Semantics in Biblical Interpretation, Poythress (2005) analyzes the concepts of truth and fullness of meaning and their relation to how the rigors and objectivity of biblical interpretation are understood in different contexts. The author begins by discussing the nature of language from several theoretical standpoints and by identifying the assumptions behind each one of them. Then, he problematizes the concept of symbolic logic as a basis for biblical interpretation and then discusses the contributions of structural linguists Saussure, Bloomfield, and Chomsky. Within this apparently alien discussion, the contributions of Eugene Nida are presented as central to the concepts of truth and fullness of meaning. According to the Poythress, developments of translation theories from the 20th century led to the translation of the Bible into "thousands of third-world tribal languages" (2005, p. 218), with Nida's postulates at the core of the whole translation business. Poythress argues that, while Nida was sensitive to the multifaceted nature of texts and therefore advocated for an awareness of multidimensional nature of translation, his attempt for a "science of translation" had a built-in inclination for formalism (which it claimed to actually oppose) and therefore favors reductionist interpretations of biblical texts. The author explains this claim as follows:

Now Nida's title does not say, "The Science of Translating," but "Toward a Science of Translating." The word "toward" signals that we are still feeling our way. We have not yet arrived at a full-fledged science. But the tide nevertheless holds out as a goal the reduction of translation to science. And this, I would allege, contains a built-in bias in favor of formalism, and with it an invitation to move toward a reductionist approach toward meaning. It suggests in particular that all figurative, allusive, and metaphorical language must be reduced to the level of the literal, in order to be fit for processing by the scientific machinery. (p. 223)

Poythress asserts that, overall, translation is an art which cannot and should not be approached from a reductionist perspective. The tools provided by Nida are actually good 
news to the world of Biblical translation and translation in general; however, reductionist philosophies will remain for years if translators and translation theorists do not overcome the "pressure from the prestige of scientific rigor." (Poythress, 2005, p. 227)

In Venuti versus Nida: A Representational Conflict in Translation Theory, Shureteh (2015) sharply describes Lawrence Venuti's with Eugene Nida's opposing views on the concept of equivalence, as well as on the functions of translation and what can be deemed an acceptable translation. By carefully juxtaposing the main contributions of these prominent authors, their mutual disagreements, and their seemingly irreconcilable views, Shureteh notes that Venuti, knowingly or not, ends up challenging his own criticism about Nida's dynamic equivalence. By implying that the translation of a poem should be domesticated or naturalized to preserve its essence and create a similar effect on the target audience, it would appear that Venuti ended up proposing a new type of dynamic equivalence. Regardless of whether this premise becomes accepted in the translation studies community, what is evident is that, at least in his lecture "Translating Humor, Equivalence, Compensation, Discourse", Venuti seemed more open to reconciling with foreignizing theories with those of Eugene Nida.

The year 2015 would see the publication of Kim's essay Dynamic Equivalence: Nida's Perspective and Beyond, which aimed to "revisit Nida and explain in detail what his theoretical background was, and how it led him to Formal Correspondence and Dynamic Equivalence" (p. 60). According to Kim, between 1964 and 1969, Nida published two groundbreaking books: Toward a Science of Translating (1964) and The Theory and Practice of Translation (1969), which would pave the way for numerous academic debates in the years to come. Through his revolutionary works, the author claims, Nida changed the landscape of translation theory by: (1) shifting the focus of translations "from the form of the message to the response of the receptor" (Kim, 2015, p. 60) and (2) consolidating a linguistic theory of translation and forging a manual for translator's use. Kim (2015) argues that while Nida's claims on the priority of dynamic equivalence over formal correspondence (form of message) have been generally welcome and vastly cited by translation experts and researchers, his theoretical construct of translation process, which led to dynamic equivalence, has received little to no attention in mainstream academia.

After analyzing arguments for and counterarguments to Nida's theory of dynamic equivalence, Kim protests the fact that in Nida's view: (1) a translation critic (an academic of some reputable authority) alone should judge the responses of the receptors involved in the translated text and (2) overemphasis on the response of the receptor is likely to neglect or conceal "the genius of the source language" and thus foster "cultural adaptation" instead of actual translation (2015, p. 65). Kim concludes that two main issues need to be raised in analyzing Nida's concept of dynamic equivalence: first, the theoretician exaggeratedly avoided the analysis of the deep structure because it was too complex an issue, which is central to achieving better classification of semantic categories, and second, "the role of the translator should be extended" to include the multifaceted profile which characterizes him today $(2015$, p. 72$)$.

Following Kim's paper, in 2016 Luong published a study comparing the original English text and the Vietnamese translation (by Dang the Binh) of Shakespeare's Romeo and Juliet in order to uncover instances of semantic equivalence in the translation. To do so, Luong used the concepts of equivalence as proposed by Catford (1965), Nida and Taber 
(1982), Baker (1992), Vinay and Darbelnet (1995), House (1997), and Pym (2014), along with qualitative techniques to describe equivalence incidents in semantic features of both the source text (ST) and the target text (TT) and contrastive analysis (Luong, 2016, p. 8). After defining equivalence and the different types of equivalence as seen in classical and modern approaches to translation studies and examining the data from the TT, Luong points out that Nida's 1964 dynamic equivalence was partly present in the translation of Romeo and Juliet in circumstances where the translator needed to deal with cultural issues due to the social context for which the play was scripted, and formal equivalence was identified when poetic language was the norm (Luong, 2016, p. 10).

After Luong's study, 2017 would welcome the publication of García's A Review of the Concept of "Functional Equivalent" in Translation: Business Entity Types in Spain and in the United States, a paper signaling the importance of using functional equivalents when translating business documents. The author first discusses the difference between foreignization and domestication and how the pros and cons of using these techniques have been argued over in translation studies. To establish the importance of using functional equivalents when translating business entity types, García compares regulatory elements in business entity types in the United States and Spain. Then, she assesses the implications of not using equivalents when translating these documents. The different examples in her paper show that "the functional equivalent strategy that originates from comparative law is rarely useful in the translation of business entity types, particularly in the fields of legal, business, financial, or economic translation" (García, 2017, p. 393). The author argues that this inconsistency might be due to the fact that it is almost impossible to find concepts that are fully equivalent in two different business legal systems. García further adds that using the incorrect equivalent in a translation might lead to misunderstandings by the target reader, whereas using a more neutral term or a borrowing might lead to a functional equivalent.

In a more recent study, Huang (2018) inquired on the phenomenon of deculturation (loss of cultural meaning) in the translation of Chinese idioms in a conference proceeding paper titled Deculturation in the Translation of Chinese Idioms: Nida's Functional Equivalence Theory in Practice. The central claim in this study is that Nida's framework is likely to induce deculturation when Chinese idioms are translated into English because functional equivalence favors receptor's response; thus, the cultural notions of the source language are neglected to cater to receptor's message comprehension. In the words of Huang, "deculturation does not only weaken the aesthetic appeal of Chinese language, but also have negative effect on Chinese and western culture" (Huang, 2018, p. 17) because, on the one hand, the semantic richness of the Chinese idioms and the culture that produced them get lost in the translation process, and the western societies lose an opportunity to enrich their cultural boundaries on the other.

Even though the list of recent studies on Nida is sure to be longer, we are positive that the glimpse we are showcasing can help develop a notion of the type of scholarly discussions taking place within the span of the last two decades around the world.

Turning now to the corpus of articles dealing with the contributions by Eugene Nida and Charles Taber as a team, the first paper which adds up to the bulk of literature discussing their influence in the more contemporary milieu of translation and translation studies dates back to 1984 and is titled Connotations in Translation: The Names of Animals 
in Alice in Wonderland as Perceived by English and French Speakers, by Claude Romney. Here, Romney purports to study the connotations (as defined by Nida and Taber, 1969, p. 201, as cited by Romney, 1984, p. 45) of animal names of a French translation of Alice in Wonderland as perceived by English and French readers of the translated text. To do so, "ten French (from France) and ten British individuals were asked to free associate on a number of concepts found in a literary work and its French translation" (Romney, 1984, p. 46). The corpus of animal names included rabbit, mouse, duck, dodo, lory, eaglet, lizard, puppy, caterpillar, pigeon, Cheshire Cat, March Hare, Dormouse, Gryphon, turtle, crocodile, crab, oyster, goose, frog, and raven. The study stemmed from the difficulties posed by a number of cultural aspects found in the original text which make it difficult to translate, especially into French, whose speakers are likely to react differently to the translations of the animal names from the novel, most of which play key roles in the plot. The author concludes that, clearly, names of animals have different connotations in English and in French. An example of a difficulty originating from this fact is the translation of the word dodo, which in English simply evokes the image of a large, clumsy extinct bird, but which in French is commonly associated with "the idea of sleep, which is not contained [...] English" (Romney, 1984, p. 53). As a final thought, Romney highlights that "as far as connotations go, there is always a discrepancy between the source text and its translation, however accurate, and the effect on the readers can never be identical" (1984, p. 54).

In a more recent study from 2015, Translation of Technical Terms: A Case of Law Terms, based on Nida and Taber's 1969 premise that "a good translation focuses on the meaning or content as such and aims to preserve that intact" (p. 173, as cited in Moghadam and Far, 2015, p. 830), Moghadam and Far seek to classify the most common strategies used in the translation of legal terms from English into Persian. The aim of their research was to figure out which is the most frequent strategy used in translation of technical law terms in the process of translating from English into Persian. To answer the question, the authors examined three books containing legal technical terminology and identified the strategies employed by the Persian translators and then verified such translations with specialized dictionaries. Based on the analysis of this corpus, they concluded that the most frequent strategies used were equivalence (150 instances), followed by general word (40 instances), which in turn was followed by loan words + paraphrase (30 cases). The strategy with the lowest frequency was omission, which recorded a total of 5 instances. Moghadam and Far infer that the reasons behind equivalence being the most frequent of all may be that, firstly, the texts were translated for a special readership, which implies that the meaning must be preserved, and secondly, it would seem that the translators were more interested in presenting communicative translation than semantic translation. Where an equivalent was not possible, the translators decided to use paraphrase and more general words to convey the intended meaning.

One year later, along a similar line of inquiry, Abbasi and Koosha (2016) published Exploring Expansion and Reduction Strategies in Two English Translations of Masnavi, an article exploring the frequency in the use of expansion and reduction as semantic strategies in two translations of book one of Masnavi, a long poem written by Persian poet Rumi. To such purpose, the authors compared two English translations of the book, one by one by Whinfield (2001) and the other one by Nicholson (2004), both of whom were famous translators. Abbasi and Koosha adopted Nida and Taber's (2003) conceptual framework, which conceives expansion as a strategy to translate seemingly "untranslatable" areas of 
poetry by using more words in the target language than the ones used in the source text and reduction as a mechanism used when "several words of the source language are translated into fewer words in the target language" (Nida \& Taber, 2003; as cited in Abbasi \& Koosha, 2016, p. 220).

Following three steps for analysis (reading each original poem critically, comparing it against its two English translations, and tallying up the number of expansion and reduction strategies used), the authors concluded that both translators (Nicholson and Whinfield) used more expansions than reductions, mainly to explain the meaning of Rumi's highly condensed language in the source text. Abbasi and Koosha assert that the translation of classical poetry requires in-depth knowledge not only of the lexical makeup of the source text, but also of the cultural elements in order to "transfer both the meaning and the beauty" of the original text into the translated poem (Abbasi \& Koosha, 2016, p. 225).

Another article that helps understand the influence of Nida and Taber's framework in contemporary discussions of translation and translation studies is the one written by Ekasani in 2016. This paper studies the use of exclamation clauses in the Indonesian translation of the novel The Adventures of Tom Sawyer. In order to carry out this investigation, the scholar used the concept of translation as proposed by Nida and Taber (1974), where "translating consists in reproducing the receptor language the closest natural equivalent of the source language message, first in terms of meaning and secondly in terms of style" (as cited by Ekasani, 2016, p. 17) and Quirk's description of different sentence types in English (1976). The author points to the existence of two exclamative clauses in the source text $(\mathrm{SL})$ that can be translated into Indonesian using the same or similar structure: noun and adjective phrases. Ekasani also explains that the changes in the information (noun or adjective clause) do not change the meaning of the message that is translated into Indonesian.

So far, we have outlined some of the most recent discussions on the legacy of translation theoreticians from the 1950s and 1960s: Vinay and Darbelnet, Jakobson, Catford, and Nida and Taber. In so doing, we expect to provide a balanced perspective of the epicenters of debate and reflection around these vital figures of the translation world. However, due to issues of scope, we have left some publications unaddressed, especially some which deal with more than one theoretician at a time, hoping to articulate a more comprehensive analysis in forthcoming articles on the subject. For now, the list of such papers includes:

- Cyrus' (2009) Old Concepts, New Ideas: Approaches to Translation Shifts, a paper which outlines the evolution of the term translation shift from the perspectives of the more classical approaches of translation studies (Vinay and Darbelnet, 1958; Nida, 1964; Catford, 1965);

- Lema's (2012) Unidad de Traducción, a book chapter published in Cagnolati's La traductología: miradas para comprender su complejidad, where the term unit of translation (UT) is tackled, and its evolution described taking into account the perspective of different scholars in various moments starting in the middle of the twentieth century; 
- Jixing's (2013) Translation Definitions in Different Paradigms, where several theoretical developments from different authors and time frames are presented and the definitions of translation from the most renowned authors in the field of translation studies are discussed;

- Lavinia's Strategies Concerning the Translation of Specialized Texts, in which "several cultural aspects regarding the changes and differences in translation and the specialized terminology used in medical business" are investigated (2015: 269);

- Pym and Ayvazyan's (2015) West enters East: A Strange Case of Unequal Equivalences in Soviet Translation Theory, where the authors explain how translation studies were perceived differently during the Cold War in eastern European countries and the West;

- Munday's (2016) Introducing Translation Studies: Theories and Applications, a book that reviews and summarizes the main strands and contributions to translation studies from different epochs and, naturally, from different theoreticians;

- Ilyas Al-Titinchy's The Unit of Translation, a journal article delving into the concept of unit of translation (UT) to venture some contemporary viewpoints into this topic. Here, the author also attempts to find a correlation between the UT and both text type and text function to analyze what influences the translator's decision as to what a UT is; and

- Olfi and Sunardi's (2017) Meaning Shifts in the Indonesian Translation of Jenny Han's [novel] To All the Boys I've Loved Before, where the authors discuss how the notion of shift, as popularized by J. C. Catford in the mid 1960s, has impacted the decision-making process in the translation of the aforementioned literary work, and where other authors such as Vinay and Darbelnet and Catford also contributed to the definition of translation shift.

\section{Concluding Remarks}

The present study set out to investigate the presence of the translation theories proposed during the 1950s and the 1960s in studies published during the first two decades of the 21 st century. The inquiry follows a thematic model of organization with reference to the main discussions around each of the exponents from the time frame studied. Based on the corpus of papers reviewed, we have arrived at three major findings: 
1. The authors from the 1950s and 1960s holding a stronger theoretical presence in contemporary discussions of translation studies seem to be Vinay and Darbelnet, Nida and Taber, Jakobson, and Catford at the end of the continuum. Such presence does not necessarily correlate with a sense of acceptance to their ideas; what it does suggest is that they inspire discussion to varying degrees and that their legacy is clearly long-lived.

2. The exact degree to which the translation theories proposed by the authors from the 1950s and 1960s truly are obsolete in theoretical debate and in professional praxis could not be determined. However, our literature review does suggest that these theories are anything but obsolete. They continue to generate large bulks of theoretical and empirical research in many countries and academic settings, and their influence seems to transcend the boundaries of theoretical affinity; that is, many of the scholars writing about them do not identify themselves precisely as opponents or supporters. They tend to use their frameworks either as grounding for empirical research or as a source of critique on their benefits and downsides, of their contributions and drawbacks.

3. From the above conclusions it is evident that the translation theories proposed in the 1950s and 1960s have exerted a decisive influence in the translation studies produced mainly from 2002 to 2018. It is unclear whether such an effect is the product of acceptance or rejection of the assumptions contained in them. Due to the scope of the current study, this is an interrogative that will for now be reserved for future research.

All things considered, there are limitations in this study that need to be acknowledged and dealt with in future studies. The main limitation was the use of a small corpus of papers dealing with the time frame studied (1950s and 1960s). Being restricted to about 40 studies, our investigation lacks the statistical significance needed for generalizability. Another source of weakness which could have affected the trustworthiness of the results was access restrictions found for some of the manuscripts, which left several articles and book chapters available for purchase out of the corpus. An additional uncontrolled factor is the possibility that not enough articles were retrieved for one author or another because the search was done manually; the use of literature review software would probably have enhanced reliability.

To tackle these and other limitations, we suggest the following measures: first, conducting in-depth analyses that include a larger sample of publications; second, reviewing studies by geographical area, by language of publication, by research type (empirical vs. theoretical), or by publication type (journal articles, books, book chapters, conference papers, among others); third, extending the chronological scope of the study to 
include other decades; fourth, running empirical studies in translation-based programs (master or doctoral) to scrutinize the applicability of the translation theories in their curriculum; and fifth, contrasting the relevance of these theories against the influence of other theories on the publications produced over the same time frame herein surveyed (2002 to 2018).

Despite the limitations listed above, this research certainly offers some insights on the influence of translation theories from the 1950s and 1960s on research agendas present in the first two decades of the 21 st century. The current review has thus identified a working pattern in the literature which could be used as a baseline not only for further research, but also for decision making in translation study programs. Once more studies of a similar nature are put together, we will be in a safer position to call these findings conclusive and give way to more informed claims as to the obsolescence (or not) of translation theories which just happen to be a few decades old.

\section{References}

[1] Abbasi, A., \& Koosha, M. (2016). Exploring Expansion and Reduction Strategies in Two English Translations of Masnavi. Advances in Language and Literary Studies, 7(2), 219-225.

[2] Absalan, A., \& Falahati Qadimi Fumani, M.R. (2016). Study of Translation Strategy Applications in Clothing Brand Advertising Slogans in Iran. International Journal of English Language and Translation Studies, 4(2), 168-176. https://www.researchgate.net

[3] Baker, M. (2005). Linguistic Models and Methods in the Study of Translation. In A. P. Frank, N. Greiner, T. Hermans, H. Kittel, W. Koller, J. Lambert, F. Paul (Eds.), Übersetzung* Translation* Traduction (pp. 285-294). Walter de Gruyter.

[4] Bassnett, S. (2014). Translation Studies. Routledge.

[5] Behtash, E., \& Moghadam, M. (2017). Translation Evaluation: A Comparative Study of an Oblique Translation. International Journal of English Language \& Translation Studies, 5(2), 108-112.

[6] Da Silva, A. C. (2017). On Jakobson's Intersemiotic Translations in Asterix Comics. Comparatismi, (2), 71-81.

[7] Cagnolati, B. E. (2012). La traductología: miradas para comprender su complejidad. D Editorial de la Universidad Nacional de La Plata. https://elibro.net

[8] Catford, J. C. (1965). A Linguistic Theory of Translation: An Essay in Applied Linguistics. Oxford University Press.

[9] Chesterman, A. (2017). Reflections on Translation Theory. Benjamins Translation Library. https://doi.org/10.1075/btl.132

[10] Cyrus, L. (2009). Old Concepts, New Ideas: Approaches to Translation Shifts. MonTI, (1), 87106. https://doi.org/10.6035/MonTI.2009.1.4

[11] Delisle, J. (2006). Criticizing Translations: The Notion of Disparity. In Bowker, L. (Ed.), Lexicography, Terminology, and Translation: Text-based Studies in Honour of Ingrid Meyer (pp. 159-174). University of Ottawa Press. https://doi.org/10.2307/j.ctt1ckpgs3

[12] Ekasani, K. A. (2016). The Analysis of English - Indonesian Exclamative Clauses in the Novel Entitled The Adventures of Tom Sawyer by Mark Twain and their Indonesian Version Entitled Petualangan Tom Sawyer Translated by Djokolelono. International Journal of Linguistics, Literature and Culture, 2(1), 16-28. https://sloap.org/journals/index.php/ijllc/article/view/81

[13] García, M. (2017). A Review of the Concept of "Functional Equivalent" in Translation: Business Entity Types in Spain and in the United States. Perspectives: Translation of Economics and the Economics of Translation, 25(3), 378-396. https://doi.org/10.1080/0907676X.2017.1287207

[14] Huang, H. (2018). Deculturation in the Translation of Chinese Idioms: Nida's Functional Equivalence Theory in Practice. In Zhiwen Zhu (Ed.), 2018 International Conference on Arts, 
Linguistics, Literature and Humanities (pp. 14-18). Web of Proceedings. https://doi.org/10.25236/icallh.2018.04

[15] Ilyas Al-Titinchy, A. I. (2017). The Unit of Translation. AWEJ for translation \& Literary Studies, 1(1), 213-221. https://doi.org/10.2139/ssrn.2931964

[16] Jakobson, R. (1959). On Linguistic Aspects of Translation. In Brower, R.A., On Translation (pp. 232-239). OUP.

[17] Jia, H. (2017). A Roman Jakobson's Triadic Division of Translation Revisited. Chinese Semiotic Studies, 13(1), 31-46. https://doi.org/10.1515/css-2017-0003

[18] Jixing, L. (2013). Translation Definitions in Different Paradigms. Canadian Social Science, 9(4), 107-115. https://doi.org/10.3968/j.css.1923669720130904.2703

[19] Kalantari, E., \& Karimnia, A. (2011). Catford's Shift Model of Translation: A Drama-based Critical Inquiry. Elixir Literature, 39, 5012-5016.

[20] Kim, D. (2015). Dynamic Equivalence: Nida's Perspective and Beyond. Skase Journal of Translation and Interpretation, 8(1), 60-75.

[21] Kučera, H. (1983). Roman Jakobson. Language, 59(4), 871-883. http://www.jstor.org/stable/413375

[22] Landy, F. (1992). In Defense of Jakobson. Journal of Biblical Literature, 111(1), 105-113. https://doi.org/10.2307/3267512

[23] Lavinia, D. (2015). Strategies Concerning the Translation of Specialized Texts. Ovidius University Annals, Economic Sciences Series, XV(1): 269-274.

[24] Lema, N. (2012). Unidad de traducción. In Cagnolati, B. E., La traductología: miradas para comprender su complejidad (pp. 94-117). D - Editorial de la Universidad Nacional de La Plata. https://elibro.net

[25] Luong, V. (2016). Semantic Features of the Vietnamese Translation of Shakespeare's Romeo and Juliet. International Journal of English Language \& Translation Studies, 4(2), 46-62. http://www.eltsjournal.org

[26] Margot, J. C. (1979): Traduire sans Trahir: La Théorie de la Traduction et son Application aux Textes Bibliques. L'Age d'Homme.

[27] Mirza Suzani, S. (2018). Applying Catford's Category Shifts to the Persian Translations of Three English Romantic Poems. Journal of Language and Translation, 8(2), 25-37.

[28] Moghadam, M., \& Far, M. (2015). Translation of Technical Terms: A Case of Law Terms. Journal of Language Teaching and Research, 61(4): 830-835. http://dx.doi.org/10.17507/jltr.0604.16

[29] Molina, L., \& Hurtado, A. (2002). Translation Techniques Revisited: A Dynamic and Functionalist Approach. Meta, 47(4), 498-512. https://doi.org/10.7202/008033ar

[30] Munday, J. (2016). Introducing Translation Studies: Theories and applications. Routledge.

[31] Nida, E. A. (1964). Toward a Science of Translating. E. J. Brill.

[32] Nida, E. A., \& Taber, C. R. (1969). The Theory and Practice of Translation. E.J. Brill.

[33] Olfi, T., \& Sunardi, D. (2017). Meaning Shifts in the Indonesian Translation of Jenny Han's To All The Boys I've Loved Before. LANGUAGE CIRCLE: Journal of Language and Literature, 12(1), 41-64. http://journal.unnes.ac.id

[34] Osimo, B. (2009). Jakobson and the Mental Phases of Translation. Mutatis Mutandis, 2(1), 73-84. https://revistas.udea.edu.co/index.php/mutatismutandis/article/view/1770

[35] Pérez-Carbonell, M. (2017). Compulsive Translators: Are Narrators in Javier Marías's Novels Beguiled by Language? Hispanic Research Journal, 18(4), 338-351. https://doi.org/10.1080/14682737.2017.1337876

[36] Poythress, V. S. (2005). Truth and Fullness of Meaning. Fullness versus Reductionist Semantics in Biblical Interpretation. Westminster Theological Journal, 67, 211-227.

[37] Pym, A. (2014). Vinay and Darbelnet and the Politics of Translation Solutions. https://pdfs.semanticscholar.org/d046/4b7853bced1c1371b54d2864bffb9feeedf0.pdf?_ga=2.2458 45124.124694917.1583641853-874082995.1581307046

[38] Pym, A., \& Ayvazyan, N. (2015). West Enters East: A Strange Case of Unequal Equivalences in Soviet Translation Theory. 1-16. https://www.researchgate.net 
[39] Pym, A., \& Torres-Simón, E. (2015). The Pedagogical Value of Translation Solution Types. $\begin{array}{llll}\text { Perspectives: } \quad \text { Studies } & \text { in }\end{array}$ http://dx.doi.org/10.1080/0907676X.2014.928334

[40] Ray, M. K. (2008). Studies in Translation. Atlantic Publishers \& Distributors.

[41] Romney, C. (1984). Connotations in Translation: the Names of Animals in Alice in Wonderland as Perceived by English and French Speakers. Calgary Working Papers in Linguistics, 10(Summer), 45-55. http://dx.doi.org/10.11575/PRISM/28871

[42] Rull, Y., Ismail, S., \& Keong, Y. (2016). Malay Subtitles of Sexual References and Profane Language of English Films. Journal of Social Sciences and Humanities, 11(2), 370-386.

[43] Sharei, V. (2017). A Comparative Study of the Strategies Employed in "The Old Man and the Sea" Translated from English into Persian on the Basis of Vinay and Darbelnet's Model. Theory and Practice in Language Studies, 7(4), 281-286. http://dx.doi.org/10.17507/tpls.0704.06

[44] Shureteh, H. (2015). Venuti Versus Nida: A Representational Conflict in Translation Theory. International Journal of Translation, 61(1), 78-92. https://doiorg.ezproxy.sibdi.ucr.ac.cr/10.1075/babel.61.1.05shu

[45] Sütiste, E. (2008). Roman Jakobson and the Topic of Translation: Reception in Academic Reference Works. Sign Systems Studies, 36(2): 271-314.

[46] Vázquez-Ayora, G. (1977). Introducción a la traductología. Georgetown University Press.

[47] Vinay, J. P., \& Darbelnet, J. (1958). Stylistique Comparée du Français et de l'Anglais: Méthode de Traduction. Didier.

[48] Waliński, J. T. (2015). Translation Procedures. Ways to Translation, 55-67. https://www.researchgate.net

[49] Walters, D. G. (2002). From Linguistic Monument to Social Memory: Translation Strategies in Philip Polack's Version of Espriu's Primera historia D'Esther. Modern Language Review, 97(4), 863-876. https://doi.org/10.2307/3738617 